\title{
The Effectiveness of the Numbered Head Together (NHT) Learning Model in the Exposition Text Writing Skills of MA Darul Istiqamah Lappae Kabupaten Sinjai
}

\author{
Asriyani $^{1}$, Syamsudduha $^{1}$, Ambo Dalle ${ }^{1}$ \\ Email: asrinats69@gmail.com \\ ${ }^{1}$ Makassar State University Postgraduate Program, Indonesia \\ Received: October 15, 2021 \\ Revised: November 16, 2021 \\ Accepted: November 24, 2021

\begin{abstract}
This study aims to (1) describe the skills of writing expository text by applying the Numbered Head Together (NHT) learning model to the tenth-grade students of MA Darul Istiqamah Lappa'e, Sinjai Regency. (2) prove the effectiveness of the Numbered Head Together (NHT) learning model on learning to write expository texts. This study uses an experimental research design, the type of experiment used is a true experiment. This study uses the form of a written test in learning to write an exposition text. Sampling was carried out using a total sampling technique with a total of 70 students. The collected data were analyzed using descriptive statistics and inferential statistics using SPSS version 25. The results of the research data analysis showed that the application of the NHT (Numbered Head Together) learning model was more effective than the conventional learning model in learning to write Indonesian exposition texts. It is evident from the results of $t$ count $>t$ table or 2,369 $>1,995$ so it can be concluded that the hypothesis test $\mathrm{H} 1$ is accepted and $\mathrm{H} 0$ is rejected, namely the NHT model is effectively used in learning to write exposition texts. In addition, it can be proven by the average value of the experimental class is 78.4 while the average value of the control class is 76.0 . This shows that the application of the Numbered Head Together (NHT) model is more effective in learning to write Indonesian exposition texts.
\end{abstract}

Keywords: Effectiveness, Numbered Head Together (NHT) Learning, Expository Text

\section{Introduction}

Everyone has their own skills; these skills are in a person through practice and sometimes have been found in oneself through the power of the creator. Likewise with language skills, each skill is closely related to other skills, namely listening, speaking, reading, and writing skills. All of these skills have an inseparable relationship, language skills are interrelated with each other. In acquiring language skills, usually through a regular sequence relationship, when childhood we learn to listen to language then speak, and finally learn to read and write. Listening and speaking are learned before entering school. The four language skills are basically a single unit which is a single chess (Hulstijn, 2003).

Guided by the 2013 Curriculum with text-based writing skills, writing skills need to be continuously honed and trained to produce accurate and interesting text products. Based on basic competence 4.4 , one aspect of writing skills that must be mastered and developed by students is the skill of writing exposition texts. The main target of developing this skill is to explain a reality through text narratives accompanied by the building of logical ideas about a fact that is arranged systematically (Clark \& Salaman, 1998).

Writing is a learning tool that is used to communicate indirectly and pour ideas into writing (Saud et al., 2014). The skill of writing expository texts in class X MA Darul Istiqamah Lappa'e, Sinjai Regency is expected to provide benefits in terms of creativity and knowledge, courage and self-confidence, arrangement of thoughts, mastery of intelligence, and emotions. The 
teacher places more emphasis on students' reading skills than on the skills of writing an exposition text.

This is because students' motivation and interest in writing are still low, students' attention when in class is not maximized, there are still students who often daydream and talk to their friends so that there is no good interaction between teachers and students. Another factor that became the author's reason was that it started from the students' weak understanding of the exposition text caused by their lack of interest in following the lesson. The triggers for this fact are (1) lack of writing habit, (2) students' writing motivation is very low, (3) they feel burdened when they get writing assignments, (4) the material for writing expository texts is still difficult for students to understand, (5) the approach to learning to write texts. unskilled exposition.

The learning model offered by the author is good and selected to be applied in the school, namely the Numbered Heads Together (NHT) learning model (Maman \& Rajab, 2016; Irawan et al., 2017). There are several reasons behind the writer choosing this model because the Numbered Heads Together (NHT) learning model focuses on student activity in the classroom (Leasa \& Corebima, 2017). This learning model provides opportunities for students to be active and responsible to teachers and classmates, so that boredom and boredom in learning can be more fun. Especially in the skill of writing exposition texts.

Furthermore, the application of the Numbered Heads Together (NHT) learning model, learning carried out in groups can be carried out in a safe and comfortable atmosphere because each group member must help each other in the group in order to achieve effective learning objectives because the criteria for the success of the learning process can be determined by group team success. Heterogeneous groups have differences in them such as academic abilities, gender, and different social backgrounds, this can help a student to understand each other, share experiences, exchange, so that each group can contribute to group achievement. Similar to the nature of a human being as a social being who is full of dependence on people around, has shared goals and responsibilities, division of tasks, and a sense of community, so cooperative learning students can be trained and accustomed to sharing and interacting socially because cooperative is an overview of social life, and be aware of the advantages and disadvantages of each.

Based on the description above, the author took the initiative to conduct research on "The Effectiveness of the Numbered Head Together (NHT) Learning Model in Writing Exposition Text Skills for Class X MA Darul Istiqamah Lappa'e, Sinjai Regency

\section{Methods}

This study used an experimental research design, the type of experiment used was a true experiment. This type of research is a quantitative type. Pure experimental research serves to find the theoretical basis for the effect of experiments on the characteristics being studied. The use of experimental research methods is more recommended because the new product developed is clearly designed and it remains only to test its effectiveness through the application of the model in the actual situation (Mulyatiningsih, 2013).

The time of the research was carried out in August 2021. The research location was at the MA Darul Istiqamah Lappa'e school, Sinjai Regency. This research was conducted using an experimental class and a comparison class (control). A comparison group was selected that had the same characteristics but carried out activities, programs, or experienced different events (Sukmadinata, 2010: 55). The success of research is largely determined by the instruments used, because the data needed to answer research questions and test hypotheses are obtained through instruments.

There are two instruments used in this study, namely, instruments related to the implementation of learning to write exposition texts using the Numbered Heads Together (NHT) learning model

Copyright ( 2021, Journal of Asian Multicultural Research for Educational Study, Under the license CC BY-SA 4.0 
in the form of a learning implementation plan (RPP). The second instrument is a performance test of writing exposition text skills. The test was used in the initial test and the final test both in the comparison class (control) and in the experimental class. In each class, learning is carried out in three meetings.

\section{Data collection technique}

The techniques used to collect data are observation and test techniques, which will be described as follows:

\section{Observation}

Observation is an activity in research by visiting the object of research. This is done to get a direct picture of the actual situation and situation experienced by students and teachers.

\section{Test Technique}

Data collection in this study was done by test. The test kit is used to measure the effectiveness of writing exposition text skills through the Numbered Head Together (NHT) learning model. The test given to students is in the form of an exposition text. The criteria that become the focus of measurement are aspects: Content, Organization/Structure/Thesis (Opening), argumentation (content), and reaffirmation (closing), Diction, Language Use, Mechanism and Neatness. Assessment of these aspects is carried out in an integrated, analytical and holistic assessment.

\section{Results and Discusssion}

\section{Descriptive Statistical Analysis}

Descriptive Statistical Analysis of the exposition text based on the results of this pure experimental research design is characterized by the presence of two classes in the study, namely class X IPS 1 and IPS 2.

Table 1. Total Frequency and Category of Control Class Scores (Pretest)

\begin{tabular}{|l|c|c|c|}
\hline No & Value Interval & Frequency & Percentage (\%) \\
\hline 1 & $85-100$ & 0 & 0 \\
\hline 2 & $75-84$ & 5 & $16,4 \%$ \\
\hline 3 & $55-74$ & 30 & $83,6 \%$ \\
\hline 4 & $40-45$ & 0 & 0 \\
\hline 5 & $1-38$ & 0 & 0 \\
\hline Sum & & 35 & $100 \%$ \\
\hline
\end{tabular}

The total frequency and category of test scores in the pretest experimental class students showed that: 4 students were in the range of $75-84$ scores with a percentage $(12.6 \%)$; 31 students are in the vulnerable value $<75$ with a percentage $(87.2 \%)$. Thus, it can be stated that the learning of the Numbered Head Together (NHT) model in learning to write Indonesian exposition texts for class X IPS 2 students in the pretest experimental class has not been proven effective as seen by the number of students who get a score of less than 75 .

Table 2. Total Frequency and Grade Category Pos Experimental Class test

\begin{tabular}{|l|c|c|c|}
\hline No & Value Interval & Frequency & Percentage (\%) \\
\hline 1 & $85-100$ & 1 & $3,2 \%$ \\
\hline 2 & $75-84$ & 28 & $80,9 \%$ \\
\hline 3 & $55-74$ & 6 & $15,9 \%$ \\
\hline 4 & $40-45$ & 0 & 0 \\
\hline 5 & $1-38$ & 0 & 0 \\
\hline Sum & & $100 \%$ \\
\hline
\end{tabular}


The total frequency and category of test scores in post-test experimental class students showed that: 1 student was in the range of 85-100 scores with a percentage (3.2\%); 28 students are in the vulnerable score of 75-84 with a percentage (80.9\%) 6 students are in the vulnerable value of 55-74 with a percentage $(15.9 \%)$.

Thus, it can be stated that the learning of the Numbered Head Together (NHT) model in learning to write Indonesian exposition texts for class X IPS 2 students in the post-test experimental class proved effective when compared to the conventional model in the control class.

In the previous section, the findings of the ability to write exposition texts for students in class X IPS 1 and X IPS 2 were described with the effectiveness of the Numbered Head Together (NHT) learning model in the experimental class and conventional learning models in the control class, which were obtained from the results of data analysis using the SPSS version of the application. 25 .

The results of learning to write expository texts carried out by students of class X IPS 1 using the conventional model show the results of learning to write exposition texts, this is evidenced by the achievement of test scores obtained by students from 35 participants in the control class. Only 21 students who managed to achieve a score of 75 and above with an average score of 76 .

Based on the observations of researchers in the control class using the conventional learning model, it can be stated that the teachers are actively fighting while the students are only required to listen and follow what the teacher says. This is in accordance with the statement of Brooks and Brooks (Riadi, 2012: 6) that the implementation of the conventional model by the teacher emphasizes content recitation, without giving sufficient time for students to reflect on the material presented.

The results of learning to write expository texts carried out by students of class X IPS 2 with the application of the Numbered Head Together (NHT) learning model have shown good results. This is evidenced by the achievement of test scores obtained by students from 35 participants who were able to achieve a score of 75 and above as many as 29 with an average score of 78.4.

The researcher found that students were skilled in writing an exposition text using both learning models, but students who used the Numbered Head Together (NHT) learning model got a higher score than using the conventional learning model, the value of $t$ count $>t$ table or 2,369 $>1,995$ so it can be concluded that the hypothesis test $\mathrm{H} 1$ is accepted and H0, namely the Numbered Head Together (NHT) model is effectively used in learning to write exposition texts for class X MA Darul Istiqamah Lappae students, Sinjai Regency

\section{Conclusion}

The learning outcomes of exposition text writing skills in the control class using the conventional model are in the less effective category as evidenced by only 20 students who scored 75 and above with an average score of 76. The learning outcomes of exposition text writing skills in the experimental class using the Numbered learning model Head Together (NHT) is included in the effective category as evidenced by 29 students who scored 75 and above with an average score of 78.4. The application of the Numbered Head Together (NHT) model in learning to write Indonesian exposition texts for class X MA Darul Istiqamah Lappae, Sinjai Regency can be said to be effective as evidenced by the results of the $t$ arithmetic $>t$ table or 2,369>1,995 so it can be concluded that the hypothesis test $\mathrm{H} 1$ is accepted and $\mathrm{H} 0$ is rejected , namely the NHT model is effectively used in learning to write expository texts in class X MA Darul Istiqamah Lappae, Sinjai Regency. 


\section{References}

Clark, T., \& Salaman, G. (1998). Telling tales: Management gurus' narratives and the construction of managerial identity. Journal of Management studies, 35(2), 137-161.

Hulstijn, J. H. (2003). Connectionist models of language processing and the training of listening skills with the aid of multimedia software. Computer Assisted Language Learning, 16(5), 413-425.

Irawan, A., \& Saputro, D. R. S. (2017, June). Experimentation of cooperative learning model Numbered Heads Together (NHT) type by concept maps and Teams Games Tournament (TGT) by concept maps in terms of students logical mathematics intellegences. In Journal of Physics: Conference Series (Vol. 855, No. 1, p. 012019). IOP Publishing.

Leasa, M., \& Corebima, A. D. (2017). The effect of numbered heads together (NHT) cooperative learning model on the cognitive achievement of students with different academic ability. In Journal of Physics: Conference Series (Vol. 795, No. 1, p. 012071). IOP Publishing.

Maman, M., \& Rajab, A. A. (2016). The Implementation of Cooperative Learning Model" Number Heads Together"(" NHT") in Improving the Students' Ability in Reading Comprehension. International Journal of Evaluation and Research in Education, 5(2), 174-180.

Mulyatiningsih, I. S. (2014). Ekperimentasi Model Pembelajaran Structure Number Heads (SNH) dan Make a Match Materi Garis dan Sudut terhadap Prestasi Belajar Siswa Kelas VII SMP Negeri 15 Purworejo Tahun Ajaran 2013/2014 (Doctoral dissertation, Pendidikan Matematika-FKIP). Sukmadinata, N. S. (2010). Pengembangan model pembelajaran terpadu berbasis budaya untuk meningkatkan apresiasi siswa terhadap budaya lokal. Cakrawala Pendidikan, (2), 81228.

Saud, S., Jufri, A., \& Rahman, M. A. (2014). Learning devices development on descriptive writing for foreign language based on berlo's smcr communication model of secondary school student. Journal of Language Teaching and Research, 5(5), 1033. 